\title{
Priming dendritic cells forTh2 polarization: lessons learned from helminths and implications for metabolic disorders
}

\section{Leonie Hussaarts $^{1}$, Maria Yazdanbakhsh ${ }^{1}$ and Bruno Guigas ${ }^{1,2}$ *}

1 Department of Parasitology, Leiden University Medical Center, Leiden, Netherlands

2 Department of Molecular Cell Biology, Leiden University Medical Center, Leiden, Netherlands

\section{Edited by:}

Dragana Jankovic, National Institutes of Health, USA

Reviewed by:

António Gil Castro, University of Minho, Portugal

David Escors, University College London, UK

\section{${ }^{*}$ Correspondence:}

Bruno Guigas, Department of

Parasitology, Leiden University

Medical Center, P.O. Box 9600,

Postzone L40-Q, Leiden 2300 RC, Netherlands

e-mail:b.g.a.guigas@lumc.nl
Nearly one quarter of the world's population is infected with helminth parasites. A common feature of helminth infections is the manifestation of a type 2 immune response, characterized by T helper 2 (Th2) cells that mediate anti-helminth immunity. In addition, recent literature describes a close association between type 2 immune responses and wound repair, suggesting that aTh2 response may concurrently mediate repair of parasite-induced damage. The molecular mechanisms that govern Th2 responses are poorly understood, although it is clear that dendritic cells (DCs), which are the most efficient antigen-presenting cells in the immune system, play a central role. Here, we review the molecular mechanisms by which DCs polarize Th2 cells, examining both helminth antigens and helminth-mediated tissue damage as Th2-inducing triggers. Finally, we discuss the implication of these findings in the context of metabolic disorders, as recent literature indicates that various aspects of the Th2-associated inflammatory response contribute to metabolic homeostasis.

Keywords: antigen-presenting cells, dendritic cells, helminth, Th2 cells, obesity, metabolic diseases, insulin resistance, type 2 inflammation

\section{INTRODUCTION}

Helminths are parasitic worms that infect one quarter of the world's population. They classically evoke strong type 2 immune responses characterized by the induction of T helper 2 (Th2) cells, which secrete cytokines like IL-4, IL-5, and IL-13. These promote IgE production by B cells, and recruitment of eosinophils and alternatively activated macrophages. Together, these events control infection and/or mediate parasite expulsion through smooth muscle contraction and mucus production [reviewed in Ref. $(1,2)]$.

Helminths enter, migrate, and exit through their host, causing considerable tissue damage along the way. Therefore, it may not be surprising that recent literature has described a close association between type 2 immune responses and wound repair (3-6). In this context, a Th2-cell associated response would contribute to both wound repair and control of parasite infection, and seems beneficial over a type 1 response, which harbors a greater risk of inducing collateral tissue damage (1). In addition, various aspects of the type 2 immune response have been shown to contribute to metabolic homeostasis (7). Indeed, helminths were recently found to protect against diet-induced insulin resistance $(8,9)$, and a negative association exists between helminth infection and metabolic syndrome (10).

The mechanisms that initiate Th2 responses are not fully understood, even though it is clear that dendritic cells (DCs), the most efficient antigen-presenting cells (APCs) in the immune system, play a crucial role (11). Since helminths are the strongest natural inducers of type 2 immune responses, many advances in dissecting the mechanisms underlying Th2 polarization have been made using either models of helminth infection or helminth-derived products. In this Mini Review, we discuss recent advances in the field, examining both helminth antigens and helminth-mediated tissue damage as triggers for the initiation of a Th2 response. In addition, we discuss the potential implications of these findings in the context of metabolic disorders.

\section{DENDRITIC CELL SUBSETS ASSOCIATED WITH Th2 POLARIZATION}

The importance of DCs in Th2 skewing is highlighted by studies showing that depletion of $\mathrm{CD} 11 \mathrm{c}^{+}$DCs interferes with the induction of a Th2 response to Schistosoma mansoni and Heligmosomoides polygyrus (12-14). Interestingly, it has become increasingly clear that distinct DC subsets induce different Th responses [reviewed in Ref. $(11,15)]$, and in the last few years, several studies analyzed the role of DC subsets in the initiation of Th2 responses to helminth infection. For example, two independent groups recently showed that the development of a Th2 response to Nippostrongylus brasiliensis depends on dermal CD301b ${ }^{+}$DCs $(16,17)$. Specifically, depletion of CD301b ${ }^{+}$DCs prior to infection reduces IL- 4 production by $\mathrm{CD} 4^{+} \mathrm{T}$ cells, without affecting the percentage of $\mathrm{T}$ follicular helper (Tfh) cells or germinal center B cells (16). Mechanistically, Th2-inducing PDL2 ${ }^{+} \mathrm{CD} 301 \mathrm{~b}^{+}$ DCs were shown to depend on DC-specific expression of the transcription factor interferon regulatory factor 4 (IRF4) (17). In line with these findings, CD $11 \mathrm{c}^{\text {int }} \mathrm{MHCII}{ }^{\text {hi }}$ dermal DCs expressing PDL2 and CD301b were also identified as a Th2-priming DC subset in $N$. brasiliensis infection (18). Of note, CD301b ${ }^{+}$DCs alone are insufficient to generate a Th2 response in vitro (17) or in vivo (16), suggesting that additional requirements exist. For example, optimal localization of DCs within the lymph node may play a crucial role. In H. polygyrus infection, CXCR5-expressing CD11 ${ }^{+}$DCs migrate to the lymph node and localize adjacent 
to B cell follicles (19). Depletion of CXCR5 or B cell-derived lymphotoxin alters the localization of the DCs and, as a consequence, impairs the development of Tfh and Th2 cells (19). In addition, it has been suggested that DCs require signals from basophils (20) and group 2 innate lymphoid cells (ILC2s) (21) to prime Th2 responses to allergens. Together, these studies suggest that specific DC subsets, as well as the microenvironment in which these subsets encounter $\mathrm{CD} 4^{+} \mathrm{T}$ cells, are important for Th2 development in vivo.

\section{PRIMING DENDRITIC CELLS FOR Th2 POLARIZATION SENSING HELMINTH-DERIVED ANTIGENS}

Dendritic cells are equipped with pattern recognition receptors (PRRs) that recognize a wide array of pathogen-associated molecular patterns (PAMPs). The classical paradigm describes that triggering of PRRs, including the Toll-like receptors (TLRs), RIGI-like receptors, NOD-like receptors, scavenger receptors, and C-type lectin receptors (CLRs), induces DC maturation and subsequent antigen-specific activation of Th cells (22).

While signaling through most TLRs induces Th1/Th17 responses (23), Th2-inducing helminth-derived molecules have also been described to interact with DCs through TLR2, 3, and 4 (24-27). Although the schistosome-related glycan LNFPIII, which contains Lewis $\mathrm{X}\left(\mathrm{Le}^{\mathrm{X}}\right)$ trisaccharides, requires TLR4 for Th2 skewing (28), various studies suggest that TLRs are dispensable for Th2 polarization by helminth antigens. For example, bone marrowderived DCs (BMDCs) from TLR2- and TLR4-knockout mice can still skew Th2 when pulsed with $S$. mansoni soluble egg antigens (SEA) (29), and the TLR adaptor protein MyD88 is not required for Th2 skewing by SEA-stimulated splenic DCs (30). Interestingly, human monocyte-derived dendritic cells (moDCs) stimulated with phosphatidylserine lipids from schistosomes induce IL-10producing T cells through TLR2 (25). Therefore, helminth products may employ TLRs for the induction of regulatory responses, but it seems that other PRRs are required for the initiation of a Th2 response.

Indeed, CLRs that sense helminth glycans play an important role in Th2 skewing. For example, SEA is internalized by moDCs through DC-specific ICAM-3-grabbing non-integrin (DC-SIGN), macrophage galactose-type lectin (MGL), and mannose receptor (MR) (31), and binds to Dectin-2 on BMDCs (32). Binding of SEA to DC-SIGN was shown to depend on $\mathrm{Le}^{\mathrm{X}}$ (33), and a recent study showed that blocking DC-SIGN-associated signaling inhibits Th2 skewing (34). Likewise, excretory/secretory products from the tapeworm Taenia crassiceps (TcES) bind MR and MGL on BMDCs (35), and the Th2-skewing capacity of TcES is glycandependent (36). Since SEA and ES mixtures contain many different glycoproteins, it is difficult to pinpoint the receptor and/or the mechanism responsible for Th2 polarization. Therefore, an important contribution to the field was made when omega-1, a small glycoprotein expressing $\mathrm{Le}^{\mathrm{X}}$ residues (37), was identified as the major immunomodulatory component in SEA $(38,39)$. Generation of a glycosylation mutant revealed that omega-1 requires its glycans to condition moDCs for Th2 skewing, and to prime Th2 responses both in vitro and in vivo. Specifically, MR but not DC-SIGN, mediates recognition and internalization of omega-1 (40). In sum, these studies indicate that helminth-derived antigen preparations can bind a variety of PRRs, which may induce distinct intracellular events that promote Th2 polarization.

\section{SENSING EPITHELIAL ALARMINS}

Modulation of DCs for Th2 priming can also take place in the absence of PRR signals, in response to epithelium-derived cytokine alarmins that are released with tissue damage (41). For example, stimulation of human myeloid DCs with thymic stromal lymphopoietin (TSLP) primes naïve T cells to produce IL-4, IL-5, IL-13, and tumor necrosis factor alpha (TNF- $\alpha)(42)$. However, the role of TSLP in helminth infection remains controversial. While TSLP receptor (TSLPR) knockout mice fail to mount a protective Th2 response to Trichuris muris $(43,44)$, they do develop a Th2 response during infection with $S$. mansoni (45), $H$. polygyrus or $N$. brasiliensis (44). Interestingly, basophils rather than DCs were recently described to act as TSLP-dependent APCs for Th2 skewing in Trichinella spiralis infection (46).

A second relevant alarmin is IL-33, as stimulation of BMDCs with this cytokine promotes Th2 development $(47,48)$. In line with these findings, IL-33 treatment improves Th2 cytokine production and expulsion of T. muris (49), and mice deficient for the IL-33 receptor T1/ST2 fail to develop a Th2 response following injection with $S$. mansoni eggs (50). Importantly, T1/ST2 is not only present on DCs but also on lymphocyte subsets including ILC2s, which were shown to mediate $N$. brasiliensis expulsion in an IL-33-dependent manner (51).

Lastly, IL-25 induces the production of type 2 cytokines by ILCs, and IL-25-knockout mice show delayed initiation of type 2 cytokine responses and $N$. brasiliensis expulsion (52). Although IL-25 has not been described to act directly on DCs, it was shown to enhance cytokine production by Th2 memory cells activated by TSLP-conditioned myeloid DCs (53). Thus, multiple alarmins are released by epithelial cells and may act in concert on various immune cell types, to mediate the induction of a $\mathrm{Th} 2$ response against helminths or their eggs.

\section{INTRACELLULAR MECHANISMS ASSOCIATED WITH Th2 POLARIZATION Signaling-dependent mechanisms}

Pattern recognition receptor-mediated signaling classically induces DC maturation via mitogen-activated protein kinases (MAPK) (54). However, in contrast to microbial ligands, helminth products often fail to induce classical signs of maturation and are well-known to downregulate TLR-mediated maturation $(31,38$, 55-60). Indeed, unlike many TLR ligands, Th2-inducing compounds fail to phosphorylate p38 MAPK but instead promote phosphorylation of p42/p44 MAPK (ERK1/2) [reviewed in Ref. (61)]. ERK1/2 stabilizes c-Fos, and inhibiting either c-Fos or ERK1/2 enhances IL-12 production by moDCs (62), suggesting that activation of this pathway suppresses Th1-polarizing cytokines. Likewise, TSLP promotes ERK1/2 phosphorylation (63) and fails to induce IL-12 production by myeloid DCs $(42,64)$.

It was noted that the NF- $\kappa \mathrm{B}$ signaling pathway also seems to be involved in Th2 polarization, as SEA- or LNFPIII-stimulated BMDCs from NF- $\kappa \mathrm{B} 1$ knockout mice fail to prime a Th2 response $(65,66)$. Furthermore, it was recently demonstrated that $\mathrm{Le}^{\mathrm{X}}$ residues, via DC-SIGN, activate LSP1 in moDCs, leading to nuclear 
accumulation of the atypical NF-кB family member Bcl3 and downregulation of IL-12 mRNA. These events also seem required for SEA-induced T cell polarization, since silencing either LSP1 or Bcl3 interferes with Th2 skewing (34). Similarly, the Th2-inducing capacity of TSLP was shown to involve activation of NF- $\kappa$ B and STAT5 $(63,67)$.

Finally, SEA can signal through spleen tyrosine kinase (Syk) downstream of Dectin-2, activating the Nlrp3 inflammasome and increasing TLR-triggered release of IL- $1 \beta$ by BMDCs. However, infection of various inflammasome-deficient mice with $S$. mansoni demonstrated that activation of this pathway does not seem to favor any particular Th response (32). Thus, helminth antigens can activate signaling, and certain members of the NF$\kappa \mathrm{B}$ and ERK pathways in particular seem to play a role in Th2 polarization.

\section{Signaling-independent mechanisms}

In addition to signaling-dependent mechanisms, various helminth products harbor enzymatic activities that mediate Th2 skewing. For example, omega-1 depends on its RNase activity, which allows the molecule to cleave both ribosomal and messenger RNA, to downmodulate TLR-induced moDC maturation and IL-12 production, and to skew toward Th2 (40). Interestingly, various
Th2-inducing allergens are also RNases $(68,69)$, as well as the endogenous eosinophil-derived neurotoxin that can amplify DCmediated Th2 polarization (70). Together, these reports suggest that any RNase internalized by DCs may harbor Th2-priming capacities, through cleavage of ribosomal and/or messenger RNA. Similarly, a number of studies identified a role for cysteine protease inhibitors secreted by filarial nematodes (cystatins) in regulating host immune responses by interfering with antigen processing [reviewed in Ref. (71)]. Therefore, helminths may employ both signaling-dependent and independent mechanisms to condition DCs for Th2 skewing (Figure 1).

Of note, recent studies indicate that modulation of metabolic pathways within immune cells can regulate their function and, thereby, the outcome of the immune response (72). For example, BMDCs switch their core metabolism from mitochondrial oxidative phosphorylation to glycolysis upon TLR-ligation, and inhibition of this switch interferes with maturation, IL-12 expression, and the ability to induce $\mathrm{CD} 4^{+} \mathrm{T}$ cell proliferation (73, 74). Among the underlying mechanisms, the mammalian target of rapamycin (mTOR) was shown to control glycolytic metabolism $(75,76)$. Although we recently showed that mTOR is not involved in Th2 skewing by omega-1- or SEA-conditioned moDCs (77), the question whether helminths or their products affect glycolytic

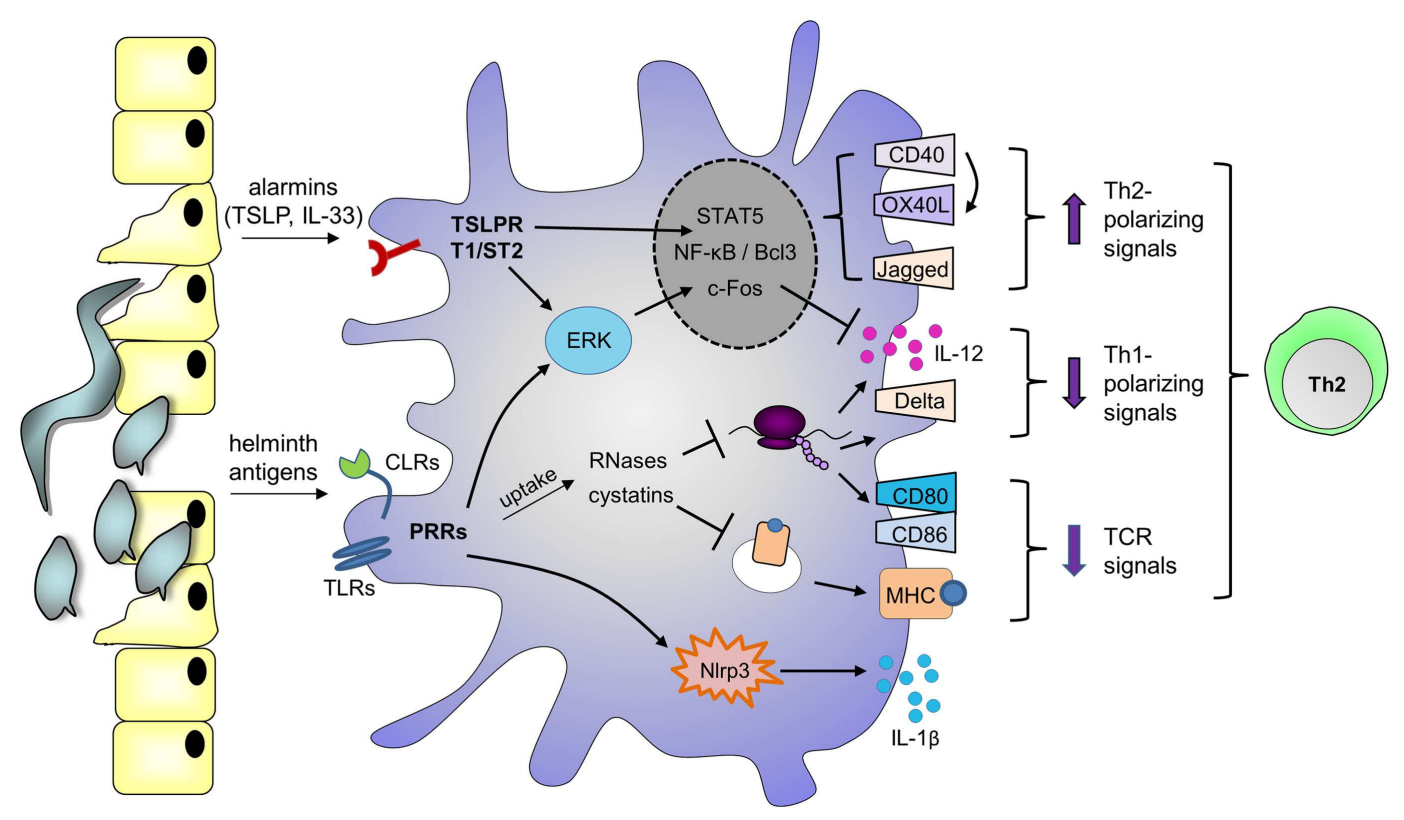

FIGURE 1 | Possible mechanisms by which helminth molecules modulate DCs for Th2 polarization. Helminth antigens are recognized by DCs through ligation of pattern recognition receptors (PRRs), such as Toll-like receptors (TLRs) and C-type lectin receptors (CLRs). Depending on the antigen, binding promotes phosphorylation of ERK1/2, nuclear accumulation of NF-kB or Bcl3, and/or activation of the NIrp3 inflammasome, which mediates IL-1 $\beta$ secretion. Phosphorylation of ERK1/2 stabilizes c-Fos, leading to downregulation of IL-12 expression. In addition, DCs can upregulate expression of Th2-associated CD40 and Jagged, which are under the control of NF-KB and ERK1/2, respectively $(115,116)$. Upon encounter of T cells expressing CD40L, signaling through CD40 promotes OX40L expression in an autocrine manner. Alternatively,
PRRs may mediate uptake of antigens that interfere with antigen presentation on MHCs, such as cystatins, or RNases that inhibit protein synthesis, thereby suppressing the expression of costimulatory molecules like CD80 and CD86. These events affect T cell receptor (TCR) signaling. As a consequence of protein synthesis inhibition, RNases may also downregulate Th1-polarizing cytokines or molecules like IL-12 and Delta-4. In parallel, helminths or their eggs damage epithelium, and alarmins are released, such as thymic stromal lymphopoietin (TSLP) and IL-33, which bind the TSLP receptor (TSLPR) and T1/ST2, respectively. TSLP can also activate ERK1/2, STAT5, and NF-kB to promote CD40 and OX40L expression. Altogether, these events favor DC-mediated Th2 polarization. 
reprograming in DCs, and how this relates to Th2 polarization, constitutes an exciting new area of research.

\section{PRIMED DCs AND INITIATION OF T CELL POLARIZATION}

A major difference between Th1 and Th2 development is that a Th1 response requires persistent production of Th1-polarizing cytokines, like IL-12, which are exclusively produced by APCs. By contrast, once primed DCs induce IL- 4 production by a few activated Th cells, the Th 2 response is self-sustained through autocrine production of IL-4 $(78,79)$. Therefore, in order to understand mechanisms of Th2 polarization, it is critical to identify the DCassociated polarizing signals that control early IL-4 production by activated $\mathrm{T}$ cells.

\section{SOLUBLE FACTORS AND SURFACE MOLECULES}

As discussed above, DCs stimulated with helminth molecules or TSLP fail to express IL-12. Moreover, injection of IL-12 can block the development of a Th2 response to S. mansoni eggs (80). These findings led to the so-called "default concept," which states that Th2 differentiation spontaneously occurs in the absence of a Th1-priming signal like IL-12. However, mice lacking IL12 do not develop a Th2 response to microbial pathogens (81), and blocking the mTOR pathway in LPS-stimulated moDCs skews a potent Th2 response without suppressing IL-12 secretion (77), suggesting that there are active signals involved in Th2 differentiation.

Such a signal may be provided by a soluble factor secreted by DCs, like RELM $\alpha$, which was shown to promote IL-10 and IL13 secretion by lymph node cells following adoptive transfer of SEA-stimulated BMDCs (82). However, supernatants from SEAprimed moDCs do not skew toward Th2 (83), and neither SEAnor omega-1-stimulated BMDCs induce Th2 when separated from $\mathrm{CD}^{+} \mathrm{T}$ cells in transwells (39), indicating that an active polarizing signal in these studies is likely provided by surface molecules. Indeed, the Notch ligands Delta- 4 and Jagged- 2 have been linked to Th1 and Th2 polarization, respectively (84), and helminth antigens were shown to upregulate Jagged- 2 on BMDCs $(85,86)$ and to suppress Delta-4 expression in moDCs (87). However, Jagged2-deficient BMDCs can still skew Th2 when challenged with SEA $(85,86)$, suggesting that other molecules may be involved. For example, CD40 has been proposed to provide a polarizing signal, as its expression on SEA-stimulated BMDCs is required for the induction of a Th2 response (88), and mice lacking CD40 ligand suffer from impaired Th2 development during S. mansoni infection (89). Mechanistically, signaling through CD40 promotes OX40L expression, which is essential for optimal Th2 skewing by SEA-conditioned BMDCs (90) and moDCs (83), as well as TSLP-conditioned myeloid DCs (64). However, treatment with anti-OX40L does not significantly affect the Th2 response to $N$. brasiliensis infection (18), and it has been suggested that OX40L acts as a costimulatory molecule rather than a polarizing signal, since SEA-treated OX40L-knockout DCs induce Th2 cells, but fail to stimulate appropriate $\mathrm{T}$ cell expansion (90). Altogether, these studies suggest that there may not be one specific DC-associated molecule required for Th2 polarization, but rather a combination of signals that mediate both optimal $\mathrm{T}$ cell priming and expansion.

\section{ROLE FOR THE T CELL RECEPTOR}

Early reports have described that the antigen dose can determine the outcome of Th differentiation, with a high dose generally favoring Th1 development (91-93). These findings were confirmed in a recent report, which also indicated that Th1-inducing adjuvants promote a higher $\mathrm{Ca}^{2+}$ flux [representing T cell receptor (TCR)-signaling strength], and induce larger synapse size, than Th2-promoting molecules (94). In addition, it has been suggested that $\mathrm{T}$ cells activated by Th2-inducing ligands are less proliferative, as priming of splenic DCs with SEA reduces the frequency of $\mathrm{CD}^{+} \mathrm{T}$ cells progressing through the cell cycle, and druginduced arrest of cell cycle progression promotes $\mathrm{Th} 2$ polarization (30). Together, these observations suggest that helminth molecules may reduce TCR triggering, impairing $\mathrm{T}$ cell proliferation in favor of Th2 differentiation. Indeed, treatment of splenic DCs with SEA results in shorter T cell-DC interaction times and lower TCR signaling when compared to a Th1-inducing adjuvant (94). In addition, omega- 1 reduces the capacity of BMDCs to form $\mathrm{T}$ cell-DC conjugates and diminishes the frequency of CD4 ${ }^{+} \mathrm{T}$ cells progressing through the cell cycle, possibly through modification of actin morphology (39). Mechanistically, interaction between $\mathrm{T}$ cells and DCs was shown to depend at least in part on the costimulatory molecule CD80 (94). As discussed above, helminth products fail to induce upregulation of costimulatory molecules, which may also explain why DCs treated with helminth molecules are less capable of forming stable interactions with $\mathrm{T}$ cells.

\section{IMPLICATIONS FOR METABOLIC DISORDERS}

The induction of a type 2 immune response has multiple functions. In the context of helminth infection, it mediates both parasite clearance and enhances wound healing. In addition, it has long been known that type 2 inflammatory responses contribute to the pathogenesis of allergy and asthma (95). Recently, however, it has become clear that multiple facets of the type 2 immune response are also involved in metabolic regulation (7). For just one example, IL-4 can regulate the balance between fatty acid and glucose oxidation in hepatocytes (96). Studying the molecular mechanisms that helminths employ to govern Th2 polarization may therefore open novel avenues for the treatment of metabolic disorders.

\section{METABOLIC DISORDERS AND TYPE 2 INFLAMMATION}

A growing body of literature indicates that obesity is associated with chronic low-grade inflammation in metabolic organs. Enhanced infiltration of classically activated M1 macrophages, $\mathrm{CD}^{+} \mathrm{T}$ cells, and Th1 cells has been reported in both liver and adipose tissues (AT) (97). This represents a key etiological mechanism promoting tissue-specific insulin resistance and impairment in whole-body glucose homeostasis, which leads to an increased risk for type 2 diabetes and cardiovascular diseases. Interestingly, various reports have shown that Th2-inducing conditions, such as $N$. brasiliensis infection $(8,9)$, allergic inflammation (96), or SEA administration (98), improve insulin sensitivity and glucose tolerance in diet-induced obese mice. In addition, both $S$. mansoni infection (99) and SEA administration (100) reduce the development of atherosclerotic lesions in mice. Furthermore, adoptive transfer of $\mathrm{CD}^{+}{ }^{+} \mathrm{T}$ cells (mostly via Th2 cells) and IL-4 treatment can protect against diet-induced insulin resistance $(96,101)$. 
Lastly, type 2-associated ILC2s (102, 103) and eosinophils (8) were shown to play a crucial role in maintenance of whole-body metabolic homeostasis by sustaining AT alternatively activated M2 macrophages. These findings are in line with epidemiological studies indicating that infection with helminths inversely correlates with metabolic syndrome $(104,105)$.

\section{THERAPEUTIC MANIPULATION OF DCS FOR THE TREATMENT OF METABOLIC DISORDERS}

The ability of DCs to prime strong Th2 responses identifies these cells as an attractive target for therapeutic manipulation of the immune system in the context of metabolic disorders. DCs are widely studied as targets for development of vaccines and immunotherapies because of their capacity to regulate a wide array of T cell responses (106-108). It has been described that DCs accumulate in AT of obese patients and mice $(109,110)$, and therapeutic manipulation of DCs might also provide a new strategy for targeted treatment of metabolic disorders (Figure 2).

In terms of $\mathrm{T}$ cell priming, isolated AT CD11 $\mathrm{c}^{+} \mathrm{F} 4 / 80^{\text {low }}$ cells from obese mice were shown to preferentially induce Th17 responses (110), and $\mathrm{AT} \mathrm{CD}_{1} 1 \mathrm{~b}^{+} \mathrm{APCs}$ isolated from insulinresistant mice promote Th1 polarization (111). However, since both AT macrophages and DCs can express CD11b, CD11c, and F4/80 (109), it is unclear which APC subset is responsible for these effects. In addition, targeting antigen to distinct DC subsets elicits distinct immune responses (112), and therefore, it remains to be determined whether AT DCs would be capable of polarizing Th2 responses in situ. These findings highlight the importance of studying AT-associated DC subsets, especially in humans, to identify appropriate subsets for therapeutic manipulation. Furthermore, it has been shown that antigen can efficiently be targeted to and processed by DCs in vivo using an antibody against CTL receptor DEC-205 $(113,114)$, a strategy which may be employed to target AT DCs. Toward this, a DC-restricted receptor on the appropriate subset needs to be identified. Lastly, directing Th2-inducing adjuvants to DCs requires single molecules that can easily be coupled to DC-specific ligands or antibodies. Therefore, proteins such as omega- 1 hold promise $(38,39)$, since they provide a powerful tool to further dissect the molecular mechanisms underlying the induction of a DC-mediated Th2 response. In particular, the identification of the receptors and/or mediators involved in Th2 polarization will provide novel insights for the development of pharmaceutical agents that mimic helminth molecules in their modulation of DCs for Th2 skewing.

\section{CONCLUDING REMARKS}

As this review illustrates, helminth molecules can interact with a variety of receptors, that either bind or internalize antigens to condition DCs for Th2 skewing through signaling-dependent and -independent mechanisms. In vivo, specific Th2-associated DC subsets are simultaneously exposed to polarizing signals from other immune cells or damaged epithelium. Depending on the helminth species and its migration through the tissue, it is likely that these signals act in concert to ensure robust

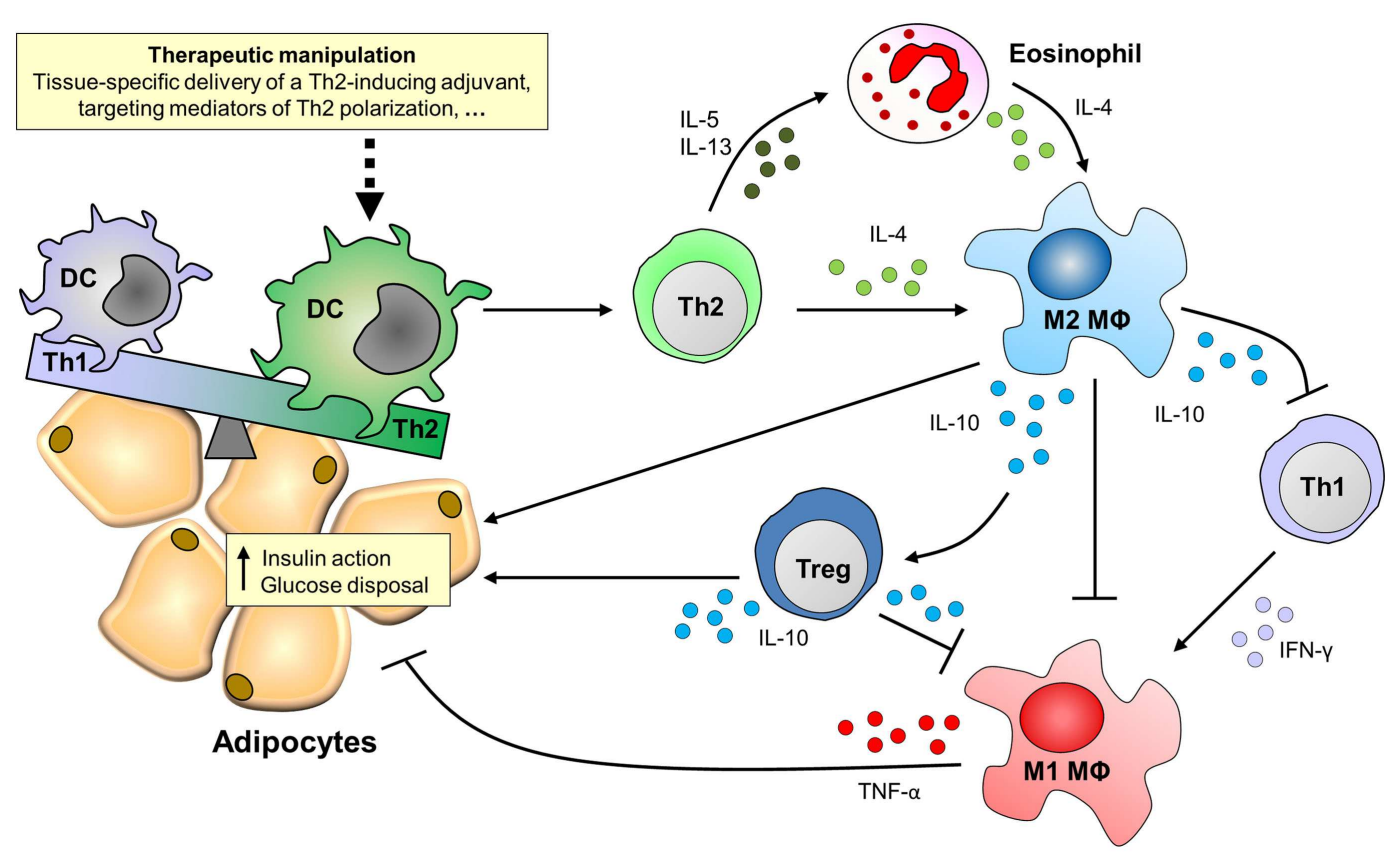

FIGURE 2 | Putative effects of targeting DCs for Th2 polarization on adipose tissue inflammation and insulin sensitivity. Adipose tissues of obese patients and high-fat diet-fed mice are characterized by the accumulation of pro-inflammatory immune cells, like Th1 cells and M1 macrophages, which mediate tissue-specific insulin resistance through secretion of pro-inflammatory cytokines like IFN- $\gamma$ and TNF- $\alpha$. By contrast, M2 macrophages that secrete IL-10 protect against insulin resistance via multiple routes. For instance, IL-10 can act directly on adipocytes to potentiate insulin signaling, inhibit Th1 cells and M1 macrophages, and induce regulatory $\mathrm{T}$ cells (Tregs), thereby promoting adipose tissue insulin sensitivity and glucose disposal. The maintenance of M2 macrophages in adipose tissue depends on the presence of IL-4, which can be derived from Th2 cells or eosinophils. Novel treatment strategies may therefore focus on therapeutic manipulation of adipose tissue dendritic cells for Th2 polarization. 
Th2 polarization, although there seems to be some redundancy. It is now recognized that type 2 immune responses can also regulate energy metabolism, and studying how helminths generate Th2 responses will not only shed light on the mechanisms that promote control of parasite infection and wound healing but may also identify pathways that contribute to metabolic homeostasis.

\section{ACKNOWLEDGMENTS}

The authors thank Bart Everts for critically reading the manuscript. This work was supported by an EFSD/Lilly Research Grant Fellowship from the European Federation for the Study of Diabetes, a SPIN-KNAW Grant from the Royal Netherlands Academy of Sciences, the EU-funded project IDEA (HEALTH-F3-2009241642), and a ZonMW TOP Grant from the Dutch Organization for Scientific Research (912-03-048).

\section{REFERENCES}

1. Gause WC, Wynn TA, Allen JE. Type 2 immunity and wound healing: evolutionary refinement of adaptive immunity by helminths. Nat Rev Immunol (2013) 13(8):607-14. doi:10.1038/nri3476

2. Anthony RM, Rutitzky LI, Urban JF Jr, Stadecker MJ, Gause WC. Protective immune mechanisms in helminth infection. Nat Rev Immunol (2007) 7(12):975-87. doi:10.1038/nri2199

3. Chen F, Liu Z, Wu W, Rozo C, Bowdridge S, Millman A, et al. An essential role for TH2-type responses in limiting acute tissue damage during experimental helminth infection. Nat Med (2012) 18(2):260-6. doi:10.1038/nm.2628

4. Monticelli LA, Sonnenberg GF, Abt MC, Alenghat T, Ziegler CG, Doering TA, et al. Innate lymphoid cells promote lung-tissue homeostasis after infection with influenza virus. Nat Immunol (2011) 12(11):1045-54. doi:10.1031/ni. 2131

5. Herbert DR, Orekov T, Roloson A, Ilies M, Perkins C, O'Brien W, et al. Arginase I suppresses IL-12/IL-23p40-driven intestinal inflammation during acute schistosomiasis. J Immunol (2010) 184(11):6438-46. doi:10.4049/ jimmunol.0902009

6. Pesce JT, Ramalingam TR, Mentink-Kane MM, Wilson MS, El Kasmi KC, Smith AM, et al. Arginase-1-expressing macrophages suppress Th2 cytokine-driven inflammation and fibrosis. PLoS Pathog (2009) 5(4):e1000371. doi:10.1371/ journal.ppat.1000371

7. Chawla A, Nguyen KD, Goh YP. Macrophage-mediated inflammation in metabolic disease. Nat Rev Immunol (2011) 11(11):738-49. doi:10.1038/nri3071

8. Wu D, Molofsky AB, Liang HE, Ricardo-Gonzalez RR, Jouihan HA, Bando JK, et al. Eosinophils sustain adipose alternatively activated macrophages associated with glucose homeostasis. Science (2011) 332(6026):243-7. doi:10.1126/ science. 1201475

9. Yang Z, Grinchuk V, Smith A, Qin B, Bohl JA, Sun R, et al. Parasitic nematodeinduced modulation of body weight and associated metabolic dysfunction in mouse models of obesity. Infect Immun (2013) 81(6):1905-14. doi:10.1128/ IAI.00053-13

10. Wiria AE, Sartono E, Supali T, Yazdanbakhsh M. Helminth infections, type-2 immune response, and metabolic syndrome. PLoS Pathog (2014) 10(7):e1004140. doi:10.1371/journal.ppat.1004140

11. Pulendran B, Tang H, Manicassamy S. Programming dendritic cells to induce $\mathrm{T}(\mathrm{H}) 2$ and tolerogenic responses. Nat Immunol (2010) 11(8):647-55. doi:10. 1038/ni.1894

12. Phythian-Adams AT, Cook PC, Lundie RJ, Jones LH, Smith KA, Barr TA, et al. CD11c depletion severely disrupts Th2 induction and development in vivo. $J$ Exp Med (2010) 207(10):2089-96. doi:10.1084/jem.20100734

13. Smith KA, Harcus Y, Garbi N, Hammerling GJ, MacDonald AS, Maizels RM. Type 2 innate immunity in helminth infection is induced redundantly and acts autonomously following CD11c(+) cell depletion. Infect Immun (2012) 80(10):3481-9. doi:10.1128/IAI.00436-12

14. Smith KA, Hochweller K, Hammerling GJ, Boon L, MacDonald AS, Maizels RM. Chronic helminth infection promotes immune regulation in vivo through dominance of CD11cloC. J Immunol (2011) 186(12):7098-109. doi:10.4049/ jimmunol.1003636
15. Briseno CG, Murphy TL, Murphy KM. Complementary diversification of dendritic cells and innate lymphoid cells. Curr Opin Immunol (2014) 29:69-78. doi:10.1016/j.coi.2014.04.006

16. Kumamoto Y, Linehan M, Weinstein JS, Laidlaw BJ, Craft JE, Iwasaki A. $\mathrm{CD} 301 \mathrm{~b}(+)$ dermal dendritic cells drive T helper 2 cell-mediated immunity. Immunity (2013) 39(4):733-43. doi:10.1016/j.immuni.2013.08.029

17. Gao Y, Nish SA, Jiang R, Hou L, Licona-Limon P, Weinstein JS, et al. Control of $\mathrm{T}$ helper 2 responses by transcription factor IRF4-dependent dendritic cells. Immunity (2013) 39(4):722-32. doi:10.1016/j.immuni.2013.08.028

18. Connor LM, Tang SC, Camberis M, Le GG, Ronchese F. Helminth-conditioned dendritic cells prime CD4+ T cells to IL-4 production in vivo. JImmunol (2014) 193(6):2709-17. doi:10.4049/jimmunol.1400374

19. Leon B, Ballesteros-Tato A, Browning JL, Dunn R, Randall TD, Lund FE. Regulation of $\mathrm{T}(\mathrm{H}) 2$ development by CXCR5+ dendritic cells and lymphotoxin-expressing B cells. Nat Immunol (2012) 13(7):681-90. doi:10. 1038/ni.2309

20. Tang H, Cao W, Kasturi SP, Ravindran R, Nakaya HI, Kundu K, et al. The T helper type 2 response to cysteine proteases requires dendritic cell-basophil cooperation via ROS-mediated signaling. Nat Immunol (2010) 11(7):608-17. doi:10.1038/ni.1883

21. Halim TY, Steer CA, Matha L, Gold MJ, Martinez-Gonzalez I, McNagny KM, et al. Group 2 innate lymphoid cells are critical for the initiation of adaptive T helper 2 cell-mediated allergic lung inflammation. Immunity (2014) 40(3):425-35. doi:10.1016/j.immuni.2014.01.011

22. Kapsenberg ML. Dendritic-cell control of pathogen-driven T-cell polarization. Nat Rev Immunol (2003) 3(12):984-93. doi:10.1038/nri1246

23. Iwasaki A, Medzhitov R. Regulation of adaptive immunity by the innate immune system. Science (2010) 327(5963):291-5. doi:10.1126/science. 1183021

24. Aksoy E, Zouain CS, Vanhoutte F, Fontaine J, Pavelka N, Thieblemont N, et al. Double-stranded RNAs from the helminth parasite Schistosoma activate TLR3 in dendritic cells. J Biol Chem (2005) 280(1):277-83. doi:10.1074/jbc. M411223200

25. van der Kleij D, Latz E, Brouwers JF, Kruize YC, Schmitz M, Kurt-Jones EA, et al. A novel host-parasite lipid cross-talk. Schistosomal lyso-phosphatidylserine activates toll-like receptor 2 and affects immune polarization. J Biol Chem (2002) 277(50):48122-9. doi:10.1074/jbc.M206941200

26. Goodridge HS, Marshall FA, Else KJ, Houston KM, Egan C, Al-Riyami L, et al. Immunomodulation via novel use of TLR4 by the filarial nematode phosphorylcholine-containing secreted product, ES-62. J Immunol (2005) 174(1):284-93. doi:10.4049/jimmunol.174.1.284

27. Correale J, Farez M. Helminth antigens modulate immune responses in cells from multiple sclerosis patients through TLR2-dependent mechanisms. $J$ Immunol (2009) 183(9):5999-6012. doi:10.4049/jimmunol.0900897

28. Thomas PG, Carter MR, Atochina O, Da'Dara AA, Piskorska D, McGuire E, et al. Maturation of dendritic cell 2 phenotype by a helminth glycan uses a Tolllike receptor 4-dependent mechanism. J Immunol (2003) 171(11):5837-41. doi:10.4049/jimmunol.171.11.5837

29. Kane CM, Jung E, Pearce EJ. Schistosoma mansoni egg antigen-mediated modulation of Toll-like receptor (TLR)-induced activation occurs independently of TLR2, TLR4, and MyD88. Infect Immun (2008) 76(12):5754-9. doi:10.1128/IAI.00497-08

30. Jankovic D, Kullberg MC, Caspar P, Sher A. Parasite-induced Th2 polarization is associated with down-regulated dendritic cell responsiveness to Th1 stimuli and a transient delay in T lymphocyte cycling. J Immunol (2004) 173(4):2419-27. doi:10.4049/jimmunol.173.4.2419

31. van LE, van Vliet SJ, Engering A, Garcia Vallejo JJ, Bank CM, SanchezHernandez M, et al. Schistosoma mansoni soluble egg antigens are internalized by human dendritic cells through multiple C-type lectins and suppress TLR-induced dendritic cell activation. Mol Immunol (2007) 44(10):2605-15. doi:10.1016/j.molimm.2006.12.012

32. Ritter M, Gross O, Kays S, Ruland J, Nimmerjahn F, Saijo S, et al. Schistosoma mansoni triggers Dectin-2, which activates the Nlrp3 inflammasome and alters adaptive immune responses. Proc Natl Acad Sci U S A (2010) 107(47):20459-64. doi:10.1073/pnas.1010337107

33. van D I, van Vliet SJ, Nyame AK, Cummings RD, Bank CM, Appelmelk B, et al. The dendritic cell-specific C-type lectin DC-SIGN is a receptor for Schistosoma mansoni egg antigens and recognizes the glycan antigen Lewis x. Glycobiology (2003) 13(6):471-8. doi:10.1093/glycob/cwg052 
34. Gringhuis SI, Kaptein TM, Wevers BA, Mesman AW, Geijtenbeek TB. Fucosespecific DC-SIGN signalling directs $\mathrm{T}$ helper cell type-2 responses via IKKepsilon- and CYLD-dependent Bcl3 activation. Nat Commun (2014) 5:3898. doi:10.1038/ncomms4898

35. Terrazas CA, Alcantara-Hernandez M, Bonifaz L, Terrazas LI, Satoskar AR. Helminth-excreted/secreted products are recognized by multiple receptors on DCs to block the TLR response and bias Th2 polarization in a cRAF dependent pathway. FASEB J (2013) 27(11):4547-60. doi:10.1096/fj.13-228932

36. Terrazas CA, Gomez-Garcia L, Terrazas LI. Impaired pro-inflammatory cytokine production and increased Th2-biasing ability of dendritic cells exposed to Taenia excreted/secreted antigens: a critical role for carbohydrates but not for STAT6 signaling. Int J Parasitol (2010) 40(9):1051-62. doi:10.1016/j.ijpara.2010.02.016

37. Meevissen MH, Wuhrer M, Doenhoff MJ, Schramm G, Haas H, Deelder AM, et al. Structural characterization of glycans on omega-1, a major Schistosoma mansoni egg glycoprotein that drives Th2 responses. J Proteome Res (2010) 9(5):2630-42. doi:10.1021/pr100081c

38. Everts B, Perona-Wright G, Smits HH, Hokke CH, van der Ham AJ, Fitzsimmons CM, et al. Omega-1, a glycoprotein secreted by Schistosoma mansoni eggs, drives Th2 responses. J Exp Med (2009) 206(8):1673-80. doi:10.1084/ jem. 20082460

39. Steinfelder S, Andersen JF, Cannons JL, Feng CG, Joshi M, Dwyer D, et al. The major component in schistosome eggs responsible for conditioning dendritic cells for Th2 polarization is a T2 ribonuclease (omega-1). J Exp Med (2009) 206(8):1681-90. doi:10.1084/jem.20082462

40. Everts B, Hussaarts L, Driessen NN, Meevissen MH, Schramm G, van der Ham AJ, et al. Schistosome-derived omega-1 drives Th2 polarization by suppressing protein synthesis following internalization by the mannose receptor. J Exp Med (2012) 209(10):1753-67. doi:10.1084/jem.20111381

41. Swamy M, Jamora C, Havran W, Hayday A. Epithelial decision makers: in search of the 'epimmunome'. Nat Immunol (2010) 11(8):656-65. doi:10.1038/ ni. 1905

42. Soumelis V, Reche PA, Kanzler H, Yuan W, Edward G, Homey B, et al. Human epithelial cells trigger dendritic cell mediated allergic inflammation by producing TSLP. Nat Immunol (2002) 3(7):673-80. doi:10.1038/ni805

43. Taylor BC, Zaph C, Troy AE, Du Y, Guild KJ, Comeau MR, et al. TSLP regulates intestinal immunity and inflammation in mouse models of helminth infection and colitis. J Exp Med (2009) 206(3):655-67. doi:10.1084/jem.20081499

44. Massacand JC, Stettler RC, Meier R, Humphreys NE, Grencis RK, Marsland BJ, et al. Helminth products bypass the need for TSLP in Th2 immune responses by directly modulating dendritic cell function. Proc Natl Acad Sci U S A (2009) 106(33):13968-73. doi:10.1073/pnas.0906367106

45. Ramalingam TR, Pesce JT, Mentink-Kane MM, Madala S, Cheever AW, Comeau MR, et al. Regulation of helminth-induced Th2 responses by thymic stromal lymphopoietin. J Immunol (2009) 182(10):6452-9. doi:10.4049/jimmunol. 0900181

46. Giacomin PR, Siracusa MC, Walsh KP, Grencis RK, Kubo M, Comeau MR, et al. Thymic stromal lymphopoietin-dependent basophils promote Th2 cytokine responses following intestinal helminth infection. J Immunol (2012) 189(9):4371-8. doi:10.4049/jimmunol.1200691

47. Besnard AG, Togbe D, Guillou N, Erard F, Quesniaux V, Ryffel B. IL-33-activated dendritic cells are critical for allergic airway inflammation. Eur J Immunol (2011) 41(6):1675-86. doi:10.1002/eji.201041033

48. Eiwegger T, Akdis CA. IL-33 links tissue cells, dendritic cells and Th2 cell development in a mouse model of asthma. Eur J Immunol (2011) 41(6):1535-8. doi:10.1002/eji.201141668

49. Humphreys NE, Xu D, Hepworth MR, Liew FY, Grencis RK. IL-33, a potent inducer of adaptive immunity to intestinal nematodes. J Immunol (2008) 180(4):2443-9. doi:10.4049/jimmunol.180.4.2443

50. Townsend MJ, Fallon PG, Matthews DJ, Jolin HE, McKenzie AN. T1/ST2deficient mice demonstrate the importance of T1/ST2 in developing primary T helper cell type 2 responses. J Exp Med (2000) 191(6):1069-76. doi:10.1084/jem.191.6.1069

51. Hung LY, Lewkowich IP, Dawson LA, Downey J, Yang Y, Smith DE, et al. IL-33 drives biphasic IL-13 production for noncanonical Type 2 immunity against hookworms. Proc Natl Acad Sci U S A (2013) 110(1):282-7. doi:10.1073/pnas. 1206587110

52. Fallon PG, Ballantyne SJ, Mangan NE, Barlow JL, Dasvarma A, Hewett DR, et al. Identification of an interleukin (IL)-25-dependent cell population that provides IL-4, IL-5, and IL-13 at the onset of helminth expulsion. J Exp Med (2006) 203(4):1105-16. doi:10.1084/jem.20051615

53. Wang YH, Angkasekwinai P, Lu N, Voo KS, Arima K, Hanabuchi S, et al. IL-25 augments type 2 immune responses by enhancing the expansion and functions of TSLP-DC-activated Th2 memory cells. J Exp Med (2007) 204(8):1837-47. doi:10.1084/jem.20070406

54. Arthur JS, Ley SC. Mitogen-activated protein kinases in innate immunity. Nat Rev Immunol (2013) 13(9):679-92. doi:10.1038/nri3495

55. Kane CM, Cervi L, Sun J, McKee AS, Masek KS, Shapira S, et al. Helminth antigens modulate TLR-initiated dendritic cell activation. J Immunol (2004) 173(12):7454-61. doi:10.4049/jimmunol.173.12.7454

56. Cervi L, MacDonald AS, Kane C, Dzierszinski F, Pearce EJ. Cutting edge: dendritic cells copulsed with microbial and helminth antigens undergo modified maturation, segregate the antigens to distinct intracellular compartments, and concurrently induce microbe-specific Th1 and helminth-specific Th2 responses. J Immunol (2004) 172(4):2016-20. doi:10.4049/jimmunol.172.4. 2016

57. Rigano R, Buttari B, Profumo E, Ortona E, Delunardo F, Margutti P, et al. Echinococcus granulosus antigen B impairs human dendritic cell differentiation and polarizes immature dendritic cell maturation towards a Th2 cell response. Infect Immun (2007) 75(4):1667-78. doi:10.1128/IAI.01156-06

58. Balic A, Harcus Y, Holland MJ, Maizels RM. Selective maturation of dendritic cells by Nippostrongylus brasiliensis-secreted proteins drives Th2 immune responses. Eur J Immunol (2004) 34(11):3047-59. doi:10.1002/eji.200425167

59. Segura M, Su Z, Piccirillo C, Stevenson MM. Impairment of dendritic cell function by excretory-secretory products: a potential mechanism for nematodeinduced immunosuppression. Eur J Immunol (2007) 37(7):1887-904. doi:10. 1002/eji.200636553

60. Brannstrom K, Sellin ME, Holmfeldt P, Brattsand M, Gullberg M. The Schistosoma mansoni protein Sm16/SmSLP/SmSPO-1 assembles into a nine-subunit oligomer with potential To inhibit Toll-like receptor signaling. Infect Immun (2009) 77(3):1144-54. doi:10.1128/IAI.01126-08

61. Everts B, Smits HH, Hokke CH, Yazdanbakhsh M. Helminths and dendritic cells: sensing and regulating via pattern recognition receptors, Th2 and Treg responses. Eur J Immunol (2010) 40(6):1525-37. doi:10.1002/eji.200940109

62. Agrawal S, Agrawal A, Doughty B, Gerwitz A, Blenis J, Van DT, et al. Cutting edge: different Toll-like receptor agonists instruct dendritic cells to induce distinct Th responses via differential modulation of extracellular signalregulated kinase-mitogen-activated protein kinase and c-Fos. JImmunol (2003) 171(10):4984-9. doi:10.4049/jimmunol.171.10.4984

63. Arima K, Watanabe N, Hanabuchi S, Chang M, Sun SC, Liu YJ. Distinct signal codes generate dendritic cell functional plasticity. Sci Signal (2010) 3(105):ra4. doi:10.1126/scisignal.2000567

64. Ito T, Wang YH, Duramad O, Hori T, Delespesse GJ, Watanabe N, et al. TSLPactivated dendritic cells induce an inflammatory $\mathrm{T}$ helper type 2 cell response through OX40 ligand. J Exp Med (2005) 202(9):1213-23. doi:10.1084/jem. 20051135

65. Artis D, Kane CM, Fiore J, Zaph C, Shapira S, Joyce K, et al. Dendritic cellintrinsic expression of NF-kappa B1 is required to promote optimal Th2 cell differentiation. JImmunol (2005) 174(11):7154-9. doi:10.4049/jimmunol.174. 11.7154

66. Thomas PG, Carter MR, Da'Dara AA, DeSimone TM, Harn DA. A helminth glycan induces APC maturation via alternative NF-kappa B activation independent of I kappa B alpha degradation. J Immunol (2005) 175(4):2082-90. doi:10.4049/jimmunol.175.4.2082

67. Bell BD, Kitajima M, Larson RP, Stoklasek TA, Dang K, Sakamoto K, et al. The transcription factor STAT5 is critical in dendritic cells for the development of TH2 but not TH1 responses. Nat Immunol (2013) 14(4):364-71. doi:10.1038/ni.2541

68. Bufe A, Spangfort MD, Kahlert H, Schlaak M, Becker WM. The major birch pollen allergen, Bet v 1, shows ribonuclease activity. Planta (1996) 199(3):413-5. doi:10.1007/BF00195733

69. Kao R, Martinez-Ruiz A, Martinez del PA, Crameri R, Davies J. Mitogillin and related fungal ribotoxins. Methods Enzymol (2001) 341:324-35. doi:10.1016/ S0076-6879(01)41161-X

70. Yang D, Chen Q, Su SB, Zhang P, Kurosaka K, Caspi RR, et al. Eosinophilderived neurotoxin acts as an alarmin to activate the TLR2-MyD88 signal pathway in dendritic cells and enhances Th2 immune responses. J Exp Med (2008) 205(1):79-90. doi:10.1084/jem.20062027 
71. Hartmann S, Lucius R. Modulation of host immune responses by nematode cystatins. Int J Parasitol (2003) 33(11):1291-302. doi:10.1016/S0020-7519(03) 00163-2

72. Pearce EL, Pearce EJ. Metabolic pathways in immune cell activation and quiescence. Immunity (2013) 38(4):633-43. doi:10.1016/j.immuni.2013.04.005

73. Krawczyk CM, Holowka T, Sun J, Blagih J, Amiel E, DeBerardinis RJ, et al. Toll-like receptor-induced changes in glycolytic metabolism regulate dendritic cell activation. Blood (2010) 115(23):4742-9. doi:10.1182/blood-200910-249540

74. Everts B, Amiel E, Huang SC, Smith AM, Chang CH, Lam WY, et al. TLRdriven early glycolytic reprogramming via the kinases TBK1-IKKvarepsilon supports the anabolic demands of dendritic cell activation. Nat Immunol (2014) 15(4):323-32. doi:10.1038/ni.2833

75. Amiel E, Everts B, Freitas TC, King IL, Curtis JD, Pearce EL, et al. Inhibition of mechanistic target of rapamycin promotes dendritic cell activation and enhances therapeutic autologous vaccination in mice. J Immunol (2012) 189(5):2151-8. doi:10.4049/jimmunol.1103741

76. Amiel E, Everts B, Fritz D, Beauchamp S, Ge B, Pearce EL, et al. Mechanistic target of rapamycin inhibition extends cellular lifespan in dendritic cells by preserving mitochondrial function. J Immunol (2014) 193(6):2821-30. doi:10.4049/jimmunol.1302498

77. Hussaarts L, Smits HH, Schramm G, van der Ham AJ, van der Zon GC, Haas $\mathrm{H}$, et al. Rapamycin and omega-1: mTOR-dependent and -independent Th2 skewing by human dendritic cells. Immunol Cell Biol (2013) 91(7):486-9. doi:10.1038/icb.2013.31

78. Dong C, Flavell RA. Cell fate decision: T-helper 1 and 2 subsets in immune responses. Arthritis Res (2000) 2(3):179-88. doi:10.1186/ar85

79. Jankovic D, Steinfelder S, Kullberg MC, Sher A. Mechanisms underlying helminth-induced Th2 polarization: default, negative or positive pathways? Chem Immunol Allergy (2006) 90:65-81. doi:10.1159/000088881

80. Oswald IP, Caspar P, Jankovic D, Wynn TA, Pearce EJ, Sher A. IL-12 inhibits Th2 cytokine responses induced by eggs of Schistosoma mansoni. J Immunol (1994) 153(4):1707-13.

81. Jankovic D, Kullberg MC, Hieny S, Caspar P, Collazo CM, Sher A. In the absence of IL-12, CD4(+) T cell responses to intracellular pathogens fail to default to a Th2 pattern and are host protective in an IL-10(-/-) setting. Immunity (2002) 16(3):429-39. doi:10.1016/S1074-7613(02)00278-9

82. Cook PC, Jones LH, Jenkins SJ, Wynn TA, Allen JE, MacDonald AS. Alternatively activated dendritic cells regulate CD4+ T-cell polarization in vitro and in vivo. Proc Natl Acad Sci U S A (2012) 109(25):9977-82. doi:10.1073/pnas. 1121231109

83. de Jong EC, Vieira PL, Kalinski P, Schuitemaker JH, Tanaka Y, Wierenga EA, et al. Microbial compounds selectively induce Th1 cell-promoting or Th2 cellpromoting dendritic cells in vitro with diverse th cell-polarizing signals. $J$ Immunol (2002) 168(4):1704-9. doi:10.4049/jimmunol.168.4.1704

84. Amsen D, Blander JM, Lee GR, Tanigaki K, Honjo T, Flavell RA. Instruction of distinct CD4 T helper cell fates by different notch ligands on antigen-presenting cells. Cell (2004) 117(4):515-26. doi:10.1016/S0092-8674(04)00451-9

85. Krawczyk CM, Sun J, Pearce EJ. Th2 differentiation is unaffected by Jagged 2 expression on dendritic cells. J Immunol (2008) 180(12):7931-7. doi:10.4049/ jimmunol.180.12.7931

86. Worsley AG, LeibundGut-Landmann S, Slack E, Phng LK, Gerhardt H, Reis e Sousa C, et al. Dendritic cell expression of the Notch ligand jagged 2 is not essential for Th2 response induction in vivo. Eur J Immunol (2008) 38(4):1043-9. doi:10.1002/eji.200737335

87. van RE, Everts B, Retra K, Phylipsen M, van Hellemond JJ, Tielens AG, et al. Combined TLR2 and TLR4 ligation in the context of bacterial or helminth extracts in human monocyte derived dendritic cells: molecular correlates for Th1/Th2 polarization. BMC Immunol (2009) 10:9. doi:10.1186/1471-217210-9

88. MacDonald AS, Straw AD, Dalton NM, Pearce EJ. Cutting edge: Th2 response induction by dendritic cells: a role for CD40. J Immunol (2002) 168(2):537-40. doi:10.4049/jimmunol.168.2.537

89. MacDonald AS, Patton EA, La Flamme AC, Araujo MI, Huxtable CR, Bauman $\mathrm{B}$, et al. Impaired Th2 development and increased mortality during Schistosoma mansoni infection in the absence of CD40/CD154 interaction. J Immunol (2002) 168(9):4643-9. doi:10.4049/jimmunol.168.9.4643

90. Jenkins SJ, Perona-Wright G, Worsley AG, Ishii N, MacDonald AS. Dendritic cell expression of OX40 ligand acts as a costimulatory, not polarizing, signal for optimal Th2 priming and memory induction in vivo. J Immunol (2007) 179(6):3515-23. doi:10.4049/jimmunol.179.6.3515

91. Constant S, Pfeiffer C, Woodard A, Pasqualini T, Bottomly K. Extent of $\mathrm{T}$ cell receptor ligation can determine the functional differentiation of naive CD4+ T cells. J Exp Med (1995) 182(5):1591-6. doi:10.1084/jem.182.5.1591

92. Hosken NA, Shibuya K, Heath AW, Murphy KM, O'Garra A. The effect of antigen dose on CD4+ $\mathrm{T}$ helper cell phenotype development in a $\mathrm{T}$ cell receptor-alpha beta-transgenic model. J Exp Med (1995) 182(5):1579-84. doi:10.1084/jem.182.5.1579

93. Boonstra A, Asselin-Paturel C, Gilliet M, Crain C, Trinchieri G, Liu YJ, et al. Flexibility of mouse classical and plasmacytoid-derived dendritic cells in directing $\mathrm{T}$ helper type 1 and 2 cell development: dependency on antigen dose and differential toll-like receptor ligation. J Exp Med (2003) 197(1):101-9. doi:10.1084/jem.20021908

94. van PN, Klauschen F, Germain RNT-. Cell-Receptor-Dependent Signal Intensity Dominantly Controls CD4(+) T Cell Polarization In vivo. Immunity (2014) 41(1):63-74. doi:10.1016/j.immuni.2014.06.003

95. Pulendran B, Artis D. New paradigms in type 2 immunity. Science (2012) 337(6093):431-5. doi:10.1126/science.1221064

96. Ricardo-Gonzalez RR, Red EA, Odegaard JI, Jouihan H, Morel CR, Heredia JE, et al. IL-4/STAT6 immune axis regulates peripheral nutrient metabolism and insulin sensitivity. Proc Natl Acad Sci U S A (2010) 107(52):22617-22. doi:10.1073/pnas.1009152108

97. Donath MY, Shoelson SE. Type 2 diabetes as an inflammatory disease. Nat Rev Immunol (2011) 11(2):98-107. doi:10.1038/nri2925

98. Bhargava P, Li C, Stanya KJ, Jacobi D, Dai L, Liu S, et al. Immunomodulatory glycan LNFPIII alleviates hepatosteatosis and insulin resistance through direct and indirect control of metabolic pathways. Nat Med (2012) 18(11):1665-72. doi: $10.1038 / \mathrm{nm} .2962$

99. Doenhoff MJ, Stanley RG, Griffiths K, Jackson CL. An anti-atherogenic effect of Schistosoma mansoni infections in mice associated with a parasite-induced lowering of blood total cholesterol. Parasitology (2002) 125(Pt 5):415-21. doi:10.1017/S0031182002002275

100. Wolfs IM, Stoger JL, Goossens P, Pottgens C, Gijbels MJ, Wijnands E, et al. Reprogramming macrophages to an anti-inflammatory phenotype by helminth antigens reduces murine atherosclerosis. FASEB $J$ (2014) 28(1):288-99. doi:10.1096/fj.13-235911

101. Winer S, Chan Y, Paltser G, Truong D, Tsui H, Bahrami J, et al. Normalization of obesity-associated insulin resistance through immunotherapy. Nat Med (2009) 15(8):921-9. doi:10.1038/nm.2001

102. Molofsky AB, Nussbaum JC, Liang HE, Van Dyken SJ, Cheng LE, Mohapatra A, et al. Innate lymphoid type 2 cells sustain visceral adipose tissue eosinophils and alternatively activated macrophages. J Exp Med (2013) 210(3):535-49. doi:10.1084/jem.20121964

103. Hams E, Locksley RM, McKenzie AN, Fallon PG. Cutting edge: IL-25 elicits innate lymphoid type 2 and type II NKT cells that regulate obesity in mice. $J$ Immunol (2013) 191(11):5349-53. doi:10.4049/jimmunol.1301176

104. Aravindhan V, Mohan V, Surendar J, Muralidhara RM, Pavankumar N, Deepa $\mathrm{M}$, et al. Decreased prevalence of lymphatic filariasis among diabetic subjects associated with a diminished pro-inflammatory cytokine response (CURES 83). PLoS Negl Trop Dis (2010) 4(6):e707. doi:10.1371/journal.pntd. 0000707

105. Chen Y, Lu J, Huang Y, Wang T, Xu Y, Xu M, et al. Association of previous schistosome infection with diabetes and metabolic syndrome: a crosssectional study in rural China. J Clin Endocrinol Metab (2013) 98(2):E283-7. doi:10.1210/jc.2012-2517

106. Steinman RM. Dendritic cells in vivo: a key target for a new vaccine science. Immunity (2008) 29(3):319-24. doi:10.1016/j.immuni.2008.08.001

107. Palucka K, Banchereau J. Cancer immunotherapy via dendritic cells. Nat Rev Cancer (2012) 12(4):265-77. doi:10.1038/nrc3258

108. Thomson AW, Robbins PD. Tolerogenic dendritic cells for autoimmune disease and transplantation. Ann Rheum Dis (2008) 67(Suppl 3):iii90-6. doi:10.1136/ard.2008.099176

109. Stefanovic-Racic M, Yang X, Turner MS, Mantell BS, Stolz DB, Sumpter TL, et al. Dendritic cells promote macrophage infiltration and comprise a substantial proportion of obesity-associated increases in CD11c+cells in adipose tissue and liver. Diabetes (2012) 61(9):2330-9. doi:10.2337/db11-1523

110. Bertola A, Ciucci T, Rousseau D, Bourlier V, Duffaut C, Bonnafous S, et al. Identification of adipose tissue dendritic cells correlated with obesity-associated 
insulin-resistance and inducing Th17 responses in mice and patients. Diabetes (2012) 61(9):2238-47. doi:10.2337/db11-1274

111. Moraes-Vieira PM, Yore MM, Dwyer PM, Syed I, Aryal P, Kahn BB. RBP4 activates antigen-presenting cells, leading to adipose tissue inflammation and systemic insulin resistance. Cell Metab (2014) 19(3):512-26. doi:10.1016/j.cmet. 2014.01.018

112. Dudziak D, Kamphorst AO, Heidkamp GF, Buchholz VR, Trumpfheller C, Yamazaki S, et al. Differential antigen processing by dendritic cell subsets in vivo. Science (2007) 315(5808):107-11. doi:10.1126/science.1136080

113. Bonifaz L, Bonnyay D, Mahnke K, Rivera M, Nussenzweig MC, Steinman RM. Efficient targeting of protein antigen to the dendritic cell receptor DEC-205 in the steady state leads to antigen presentation on major histocompatibility complex class I products and peripheral CD8+ T cell tolerance. J Exp Med (2002) 196(12):1627-38. doi:10.1084/jem.20021598

114. Bonifaz LC, Bonnyay DP, Charalambous A, Darguste DI, Fujii S, Soares H, et al. In vivo targeting of antigens to maturing dendritic cells via the DEC205 receptor improves T cell vaccination. J Exp Med (2004) 199(6):815-24. doi:10.1084/jem.20032220

115. Qin H, Wilson CA, Lee SJ, Zhao X, Benveniste EN. LPS induces CD40 gene expression through the activation of NF-kappaB and STAT-1alpha in macrophages and microglia. Blood (2005) 106(9):3114-22. doi:10.1182/blood2005-02-0759
116. Goh F, Irvine KM, Lovelace E, Donnelly S, Jones MK, Brion K, et al. Selective induction of the Notch ligand Jagged-1 in macrophages by soluble egg antigen from Schistosoma mansoni involves ERK signalling. Immunology (2009) 127(3):326-37. doi:10.1111/j.1365-2567.2008.02979.x

Conflict of Interest Statement: The authors declare that the research was conducted in the absence of any commercial or financial relationships that could be construed as a potential conflict of interest.

Received: 15 August 2014; paper pending published: 08 September 2014; accepted: 25 September 2014; published online: 20 October 2014.

Citation: Hussaarts L, Yazdanbakhsh M and Guigas B (2014) Priming dendritic cells for Th2 polarization: lessons learned from helminths and implications for metabolic disorders. Front. Immunol. 5:499. doi: 10.3389/fimmu.2014.00499

This article was submitted to T Cell Biology, a section of the journal Frontiers in Immunology.

Copyright $(2014$ Hussaarts, Yazdanbakhsh and Guigas. This is an open-access article distributed under the terms of the Creative Commons Attribution License (CC BY). The use, distribution or reproduction in other forums is permitted, provided the original author(s) or licensor are credited and that the original publication in this journal is cited, in accordance with accepted academic practice. No use, distribution or reproduction is permitted which does not comply with these terms. 